\title{
Indeterminate Cell Histiocytosis - Case Report and Review of Literature
}

\author{
Aleksandra R. VOJVODIĆ, Željko MIJUŠKOVIĆ, Lidija KANDOLF SEKULOVIĆ \\ Department of Dermatology and Veneoreology, Faculty of Medicine, Military Medical Academy, Belgrade, Serbia \\ *Correspondence: Aleksandra R. Vojvodić, E-mail: aleksandravojvodic@live.com
}

UDC 612.349.7:616-006]:616.5

\begin{abstract}
Introduction. Indeterminate cell histiocytosis is a rare proliferative disorder of indeterminate dendritic cells, reported in only 50 case reports so far. It is clinically presented as yellow, red or brown papules and nodules that appear in otherwise healthy adult individuals. Indeterminate cells are distinct dendritic cells of the skin that have ultrastructural similarities to the epidermal Langerhans cells but do not contain the characteristic Birbeck's granules and they are also langerin-negative, unlike LCH. Indeterminate cell histiocytosis is an exceptional entity with variable clinical, histopathologic or immunohistochemical findings, sharing morphologic and immunophenotypic features with both Langerhans- and non-Langerhans cell histiocytoses. Case Report. We present a case of indeterminate histiocytosis in a 77-year-old man with 3-year history of asymptomatic, multiple reddish and brown papules and nodules over the entire body, including the oral mucosa. Skin biopsy was done, and histopathological analysis with immunohistochemistry was performed. The positive ICH staining of cells for CD68, CD1a, and S-100 enabled us to diagnose ICH in our patient. Also, BRAF V600E mutation was detected in tumor tissue. The treatment was started with methotrexate that was effective for 6 months, but due to the disease recurrence, further therapy with thalidomide was advised, without effect. Conclusion. Indeterminate histiocytosis is a rare disease, therefore no standardized treatment has been established and the treatment options are limited.
\end{abstract}

Key words: Histiocytosis; Dendritic Cells; Langerhans Cells; Skin Neoplasms; Rare Diseases; Treatment Outcome

\section{Introduction}

Indeterminate cell histiocytosisis is an extremely rare variant of cutaneous histiocytosis which can be distinguished from Langerhans cell histiocytosis by three important characteristics: the lack of Birbeck granules on ultrastructural study, the absence of epidermotropism on histopathology, and the lack of extracutaneous involvement. These cells evidently express both Langerhans cell and monocyte/macrophage markers (1). It is clinically characterized by multiple asymptomatic yellow, red, or reddish brown papules and nodules that can be found in otherwise healthy individuals (2).

Indeterminate cells may present as dendritic cells histologically and immunohistochemically resembling Langerhans cells because of their expression of CD1a and S-100, but without the definitive Birbeck granules (3). The real relationship between the two types of cells has been a matter of controversy since their original finding. Because of the fact that indeterminate cells migrate into the epidermis, some authors share an opinion that their organelles may modify and may become LC (1). On contrary, in cell culture, LC usually lose Birbeck granules, resembling indeterminate cells and therefore some authors have also postulated that finding of the indeterminate cells may represent a more mature form of LC (2-4). Because of their immunophenotypic similarity, indeterminate cells are considered to be related to Langerhans cells. By definition, they express S-100 protein and CD1a, but in contrast to LCh, they do not express langerin (CD207). Furthermore, these tumors do not express any of other histiocytic and dendritic specific markers including CD163, CD30, CD21, CD23, and CD35. They are variably positive for CD45, CD68, lysozyme, and CD4 (4-6).

$\mathrm{ICHs}$ are extremely rare neoplasms of indeterminate cells and have only been re- 
ported in less than 50 cases. In most cases the patients have been presented with one or more papules, nodules, or plaques on the trunk, face, neck or extremities. Diagnosis is established based on the histopathological analysis of the lesion. In case of localized disease, further work-up with systemic CT scans and bone marrow biopsy is not indicated (5, 6 ). Treatment of the disease is not standardized due to its rarity. The treatment options include: systemic chemotherapy, PUVA, narrowband ultraviolet B phototherapy, thalidomide, pravastatin and low dose methotrexate. The disease course is usually not progressive. Recently, BRAF mutations were found in patients with certain forms of histiocytoses and treatment with BRAF inhibitors was found to be effective in some of these patients.

\section{Case Report}

A 77-year-old man presented with a 3-year history of asymptomatic multiple brown and reddish papules and nodules over the trunk and extremities and in the oral mucosa

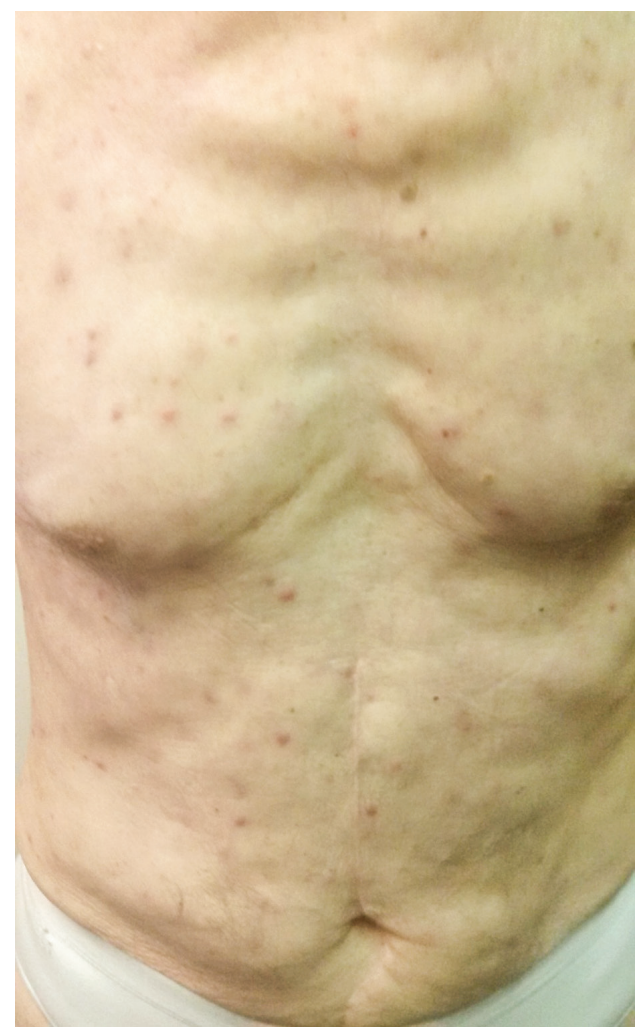

Figure 1. Asymptomatic multiple brown and reddish papules and nodules over the trunk

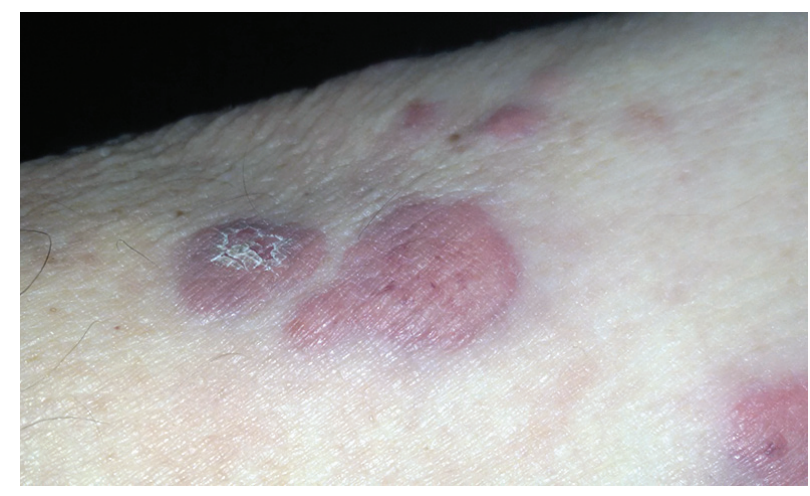

Figure 2. Reddish papules and nodules

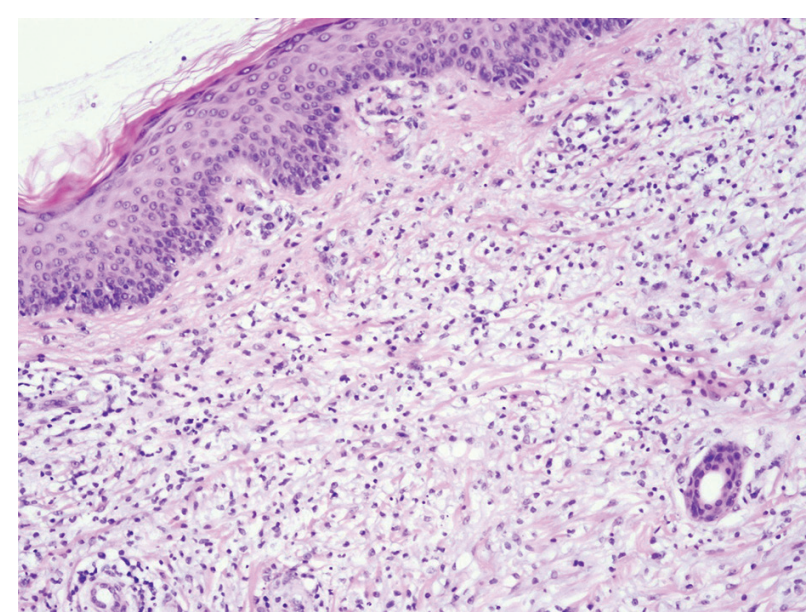

Figure 3. Histopathology revealed a diffuse, moderately mononuclear, monomorphous, nonepidermotropic infiltrate of large epithelioid cells in the upper dermis (stain type-Hematoxylin and eosin; original magnification: 100).

(Figures 1, 2, 3). The first skin biopsy was nonspecific with superficial dermal infiltrate of lymphocytes. The patient was treated with systemic corticosteroids and colchicine without response, and then with indometacin, desloratidine, dapsone and azathioprine, again without effect. The patient's history, physical examination, and routine laboratory tests did not show any systemic involvement. The erythrocyte sedimentation rate (ESR) was increased and the C-reactive protein was elevated (SE $125 \mathrm{~mm} / \mathrm{h}$; CRP 36,1 mg/l), as well as the level of lactate dehydrogenase (256 $U / L)$. The results of serum protein electrophoresis (SPEP), ANA, anti-HIV antibody, complete blood count, total proteins, serum albumin, bilirubin, cholesterol, triglycerides, 


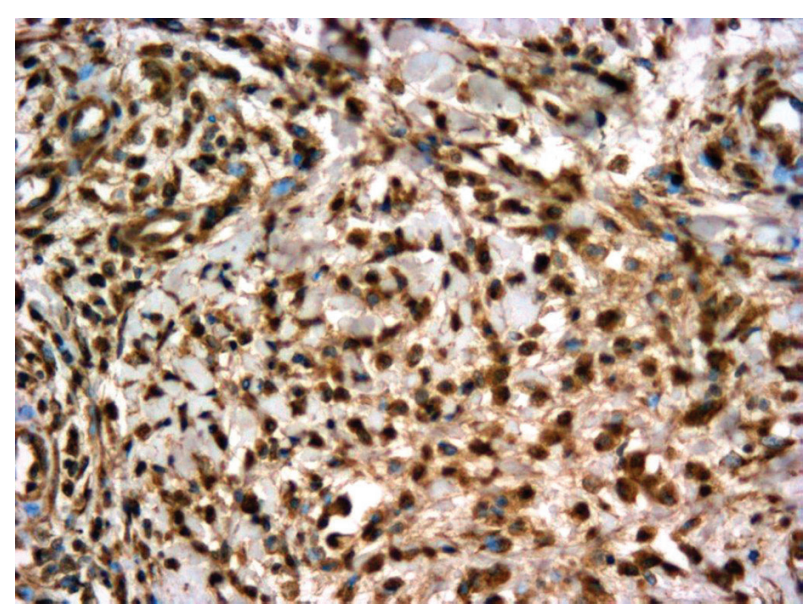

Figure 4. Immunohistochemical examination showed expression of S-100 (original magnification: 300)

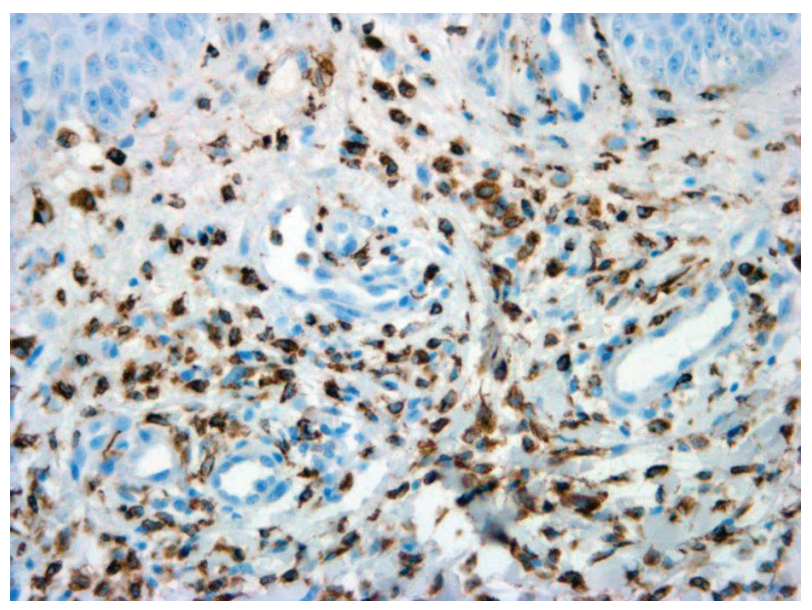

Figure 5. Immunohistochemical examination showed expression of CD 68 (original magnification: 300)

AST, ALT, CK, RF, a-CCP, IgM, IgA, IgG, C3, C4, PSA, f/t PSA were within normal range. Chest radiography, radiography of the joints of hands and feet, and ultrasound imaging of the abdomen and peripheral lymph nodes showed normal results. Skin biopsies were repeated and histological findings of the second and the third skin biopsies were also nonspecific, while diffuse, moderately active mononuclear infiltrate of small hystiocitic cells was found in the upper dermis on the forth biopsy. Histiocytes were kidney-shaped, segmented and partly with the light nucleus. Immunohistochemical examination showed histiocyte cell expression of S-100 protein and CD68, while no expression was found for

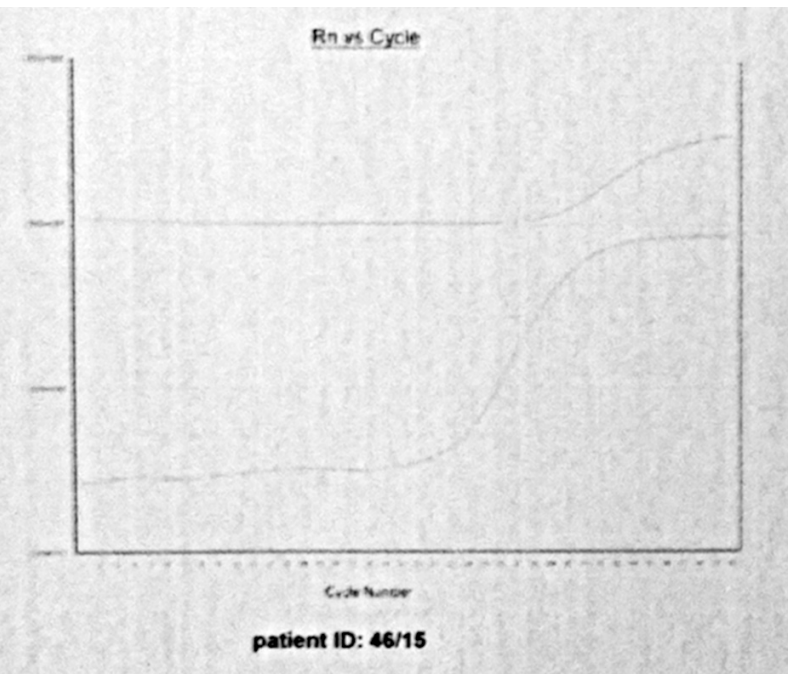

Figure 6 . The genetic analysis of BRAF mutation was done using real-time PCR

CD3, CD4, CD8, CD10, CD20, CD30 and CD1a (Figures 4, 5). Also, somatic mutation in the BRAF gene (BRAFV600E) was identified (Figure 6). Bone marrow biopsy was done and showed normal result, and TCR and BCR rearrangement analysis revealed polyclonal pattern in the bone marrow. B clonality testing in the skin tissue showed $\mathrm{IgH}$ monoclonal $\mathrm{B}$ cell infiltrate, while it was polyclonal in the peripheral blood. TCR rearrangement in the skin and peripheral blood revealed polyclonal pattern. CT of the chest, abdomen and pelvis showed normal results.

The diagnosis of indeterminate cell histiocytosis was made based on clinicopathologic and immunohistochemical findings. The patient was treated with methotrexate with regression of skin lesions (Figures 7,8 ). However, after six months, a new flare-up of generalized reddish nodules was evident, so the treatment with thalidomide was advised, but with no response. The patient was lost to follow-up and died one year later.

\section{Discussion}

Histiocytoses are a heterogeneous group of disorders characterized by the proliferation and accumulation of the cells of mononuclear-macrophage system and dendritic cells, originating from neutrophil/macrophage lineage CD34p progenitor cells in the bone marrow (3-7). Langerhans cells (LC), the proto- 


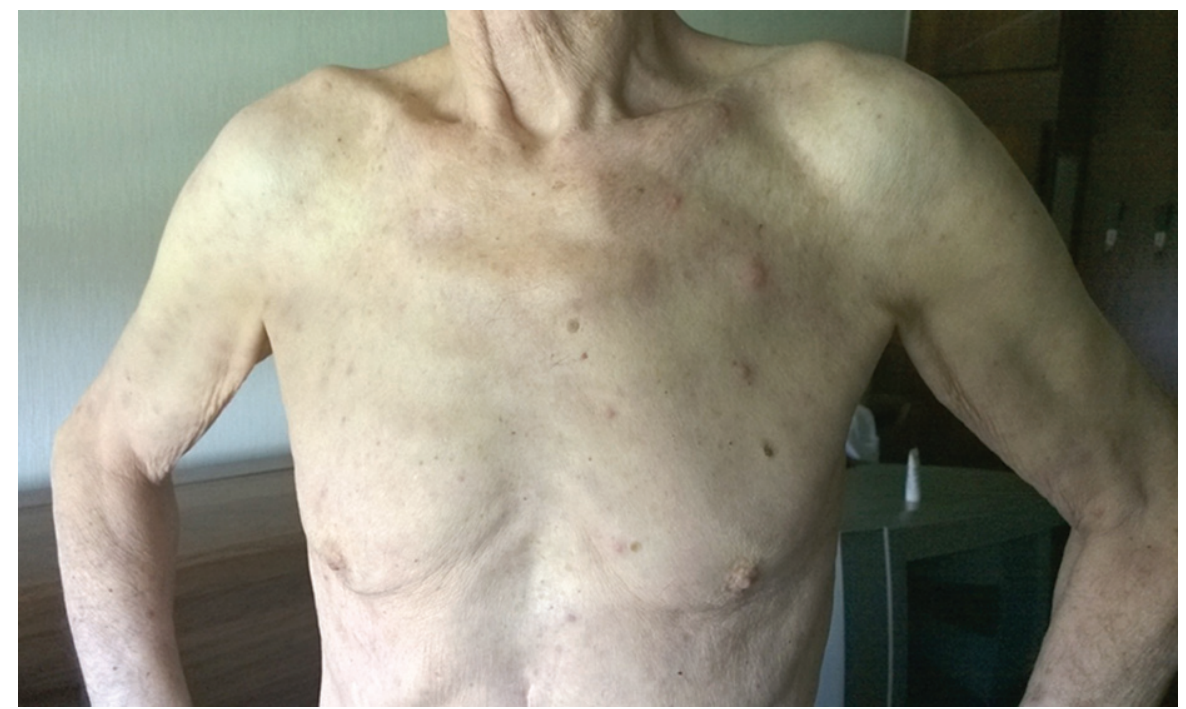

Figure 7. After treatment with methotrexate

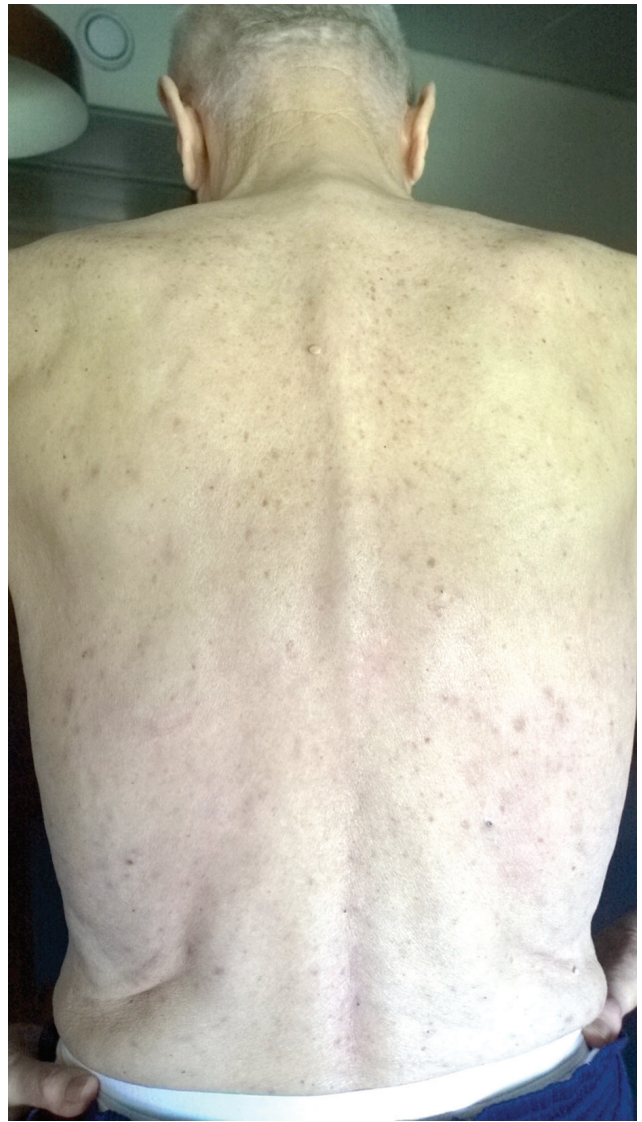

Figure 8. After treatment with methotrexate

type of dendritic cells are characterized by strong immunoreactivity for $\mathrm{S} 100$ protein and CD1a. In addition, they show Birbeck granules, a defining ultrastructural feature of LC.
Monocytes/macrophages are defined by markers, such as KP1 (CD68) or Ki-M1p.2 UItrastructurally, they show phagolysosomes, but no Birbeck granules. Occasionally, LC stain for KP1 (CD68), but then with less intensity than macrophages. Conversely, macrophages are usually negative for the LC markers, S-100 protein and CD1a. Various hypotheses regarding the relationship between LC and IC have been proposed - i.e. ICs are either immature precursors of LC and LC are precursors of IC or both are independent types of dendritic cells.

Less than 50 cases of $\mathrm{ICH}$ have been reported so far. The disease is a proliferative disorder of dendritic cells that has both immunophenotypic features of Langerhans cells (CD1a and S-100-positive) and macrophages (CD68-positive). Birbeck granules that characterize Langerhans cells cannot be detected by electron microscopy in $\mathrm{ICH}$ histiocytes. Nowadays, it is proposed that ICH could be a non-Langerhans' cell histiocytosis variant, but its pathogenesis has remained unknown (5-8).

Two theories on pathogenesis of this rare disorder have been presented in the literature. The first is in regard to the cases of $\mathrm{ICH}$ arising de novo. Since the cell of the origin is thought to be the Langerhans cell, it is believed that indeterminate cells are a phase in the development of the Langerhans cell. However, it is still uncertain whether or not the indeterminate cells are immature Langerhans 
cells that have not developed Birbeck granules or that they are Langerhans cells that have lost their Birbeck granules in their migration towards a lymph node. The second theory relates to those cases evolving from a preexisting $\mathrm{B}$ cell lymphoma. Although the cell of origin in $\mathrm{ICH}$ is from the common myeloid progenitor lineage, some cases of $\mathrm{ICH}$ have arisen in association with low grade Bcell lymphoma, leading some authors to speculate that ICH may be the result of B-cell dedifferentiation, caused by a so far unknown mechanism $(8,9)$.

Histologically, there is a diffuse dermal infiltration of cells with irregular nuclear grooves and clefts that resemble Langerhans cells. These cells are without Birbeck granules on electron microscopy and desmosomes; however they contain cell processes. On immunohistochemistry, these cells are S100 and CD1a positive and are negative for CD21, CD23, CD35, langerin, and B and T cell markers (13). Although langerin immunostaining was not available at the time of diagnosis, the histopathological analysis with immunohistochemical profiling was consistent with the diagnosis of $\mathrm{ICH}$ in our patient.

Recently, a somatic mutation in the BRAF gene (BRAF V600E) was identified in Langerhans cell histiocytosis and Eredheim-Chester disease tissue infiltrates, suggest- ing a common origin of both histiocytoses and leading to the reclassification of these disorders (12-14). The presence of BRAF mutation in indeterminate cell histiocytosis was also described in case reports, as well as in our patient $(5,10)$.

$\mathrm{ICH}$ is a localized or generalized, and almost exclusively cutaneous disease (9-12). A study done by Ratzinger et al reported on 18 patients with indeterminate cell histiocytosis who were followed up from six months to seven years after their initial diagnosis. In this study, the majority of patients with the localized disease experienced complete resolution after excision. The disease tended to become stable in the patients having more widespread lesions, even without specific treatment. Only two patients developed a slow progression of skin lesions. Two patients in this cohort developed a systemic disease, one with lesions of the eye and the other with lesions of the bone. Neither deaths nor other serious illnesses were reported as related to $\mathrm{ICH}$ in this study, thus supporting the premise that $\mathrm{ICH}$ runs a benign course, regardless of the skin lesion distribution (solitary or diffuse variant). One case report documents the remission and recurrence without treatment but there are reports of remission and recurrence also with chemotherapy. Even though it is rare, there are cases with systemic involvement,

Table 1 Treatment modalities for $\mathrm{ICH}$ and their effects in previous case reports

\begin{tabular}{ccccc}
$\begin{array}{c}\text { Number } \\
\text { of patients }\end{array}$ & $\begin{array}{c}\text { Immunostaining of the } \\
\text { dermal cell infiltrate }\end{array}$ & Treatment modality & Treatment efficacy & Reference \\
1 & CD1, CD68, S100 & nbUVB & Short term & $\begin{array}{c}\text { Nogueira Zerbini MC, } \\
\text { 2016. (20) }\end{array}$ \\
1 & CD1, S100 & nbUVB & Complete & Ishibashi M, 2008. (21) \\
1 & S100- & nbUVB & Complete & Bard S, 2011. (22) \\
1 & S100, CD68 & methotrexate & Complete & Fornier J, 2011. (23) \\
1 & S100, CD 1- & thalidomide & Complete & Toth B, 2012. (24) \\
1 & CD1, S100, CD68 & thalidomide & Complete & Ventura, 2010. (27) \\
1 & CD1, S100 & EBT+ 2-chlorodeoxyadenosine & Complete & Adam Z, 2017. (26) \\
1 & CD1, S100 & PUVA & Without effect & Adam Z, 2017. (26) \\
1 & CD1, S100, CD68 & pravastatin & Complete & Burns MV, 2011.(28) \\
1 & S100, CD68 & methorexate & Short term & Vojvodic A, 2018. \\
\hline
\end{tabular}

Abbreviations: nbUVB- narrowband UVB, PUVA- psoralen and UVA, EBT- electron beam therapy 
resistant to the chemotherapy with the lethal outcome. Our patient was treated for 6 months with methotrexate with a temporary resolution of skin lesions, but with a further relapse and unsuccessful treatment with thalidomide. He was lost to follow-up and he died a year later, and further details from his medical history were unavailable.

There is no standardized treatment for $\mathrm{ICH}$ (Table 1) (14-17). As ICH has a benign clinical course, conservative management is the best approach. In some cases, skin lesions were resolved spontaneously. Some treatments that have been used with various success include systemic chemotherapy, PUVA, narrowband Ultraviolet $B$, thalidomide, pravastatin and low dose methotrexate with a generally good therapeutic response. Chemotherapy must be used for aggressive cutaneous ICH, which involves over $50 \%$ of the body surface area and lasts for at least 6 months with no spontaneous resolution and new appearing lesions. There are four reports of $\mathrm{ICH}$ association with malignancies: one case of mast cell leukemia, another patient with myelomonocytic leukemia, and two cases with low grade B-cell lymphomas $(8,14,18)$. Our case was not associated with hematologic malignancy, which was ruled out. Our patient's clinical history, physical examination and routine laboratory tests did not show any systemic involvement. TCR and BCR rearrangement analyses revealed polyclonal infiltrate in the bone marrow. Monoclonal IgH B cell infiltrate was found in a skin sample, while it was polyclonal in the peripheral blood, which was described previously in these entities (19).

\section{Conclusion}

Indeterminate cell histiocytosis is a rare disorder of cutaneous histiocytic/dendritic system development, but the true pathogenesis is still unknown. It can be found mostly in adults and must be diagnosed only on the basis of a thorough clinical investigation, repeated skin biopsies, histopathological, immunohistochemical and molecular analysis. In our patient, treatment with methotrexate led to transient resolution of lesions, while further thalidomide treatment was inefficient. Targeted inhibition of BRAF-V600E with combined $B R A F$ and MEK inhibitors could be a good option and might be a promising therapy for patients with treatment resistant disease. Further research in these groups of rare disorders is needed to widen the treatment options for these patients.

\section{Abbreviations}

$\mathrm{LCH}$, LC - Langerhans cells

Lh - Langerhans

$\mathrm{ICH}$ - Indeterminate cell histiocytosis

IC - Indeterminate cell

\section{References}

1. Hammonds L, Snow L. Indeterminate cell histiocytosis: a case report and novel immunohistochemical finding. J Am Acad Dermatol. 2009;60(3 Suppl 1):AB74.

2. Yin R, Zheng WJ, Yang XC, Hao F. Recurrent generalized indeterminate cell histiocytosis: a case report. J Am Acad Dermatol. 2010;63(1):e3-5.

3. Burns MV, Ahmed A, Callahan GB, Le LQ, Cockerell C. Treatment of indeterminate cell histiocytosis with pravastatin. J Am Acad Dermatol. 2011;64(5):e85-6.

4. Ferran M, Toll A, Gilaberte M, Barranco C, Lloreta J, Pujol RM. Acquired mucosal indeterminate cell histiocytoma. Pediatr Dermatol. 2007;24(3):253-6.

5. O'Malley DP, Agrawal R, Grimm KE, Hummel J, Glazyrin A, Dim DC. Evidence of BRAF V600E in indeterminate cell tumor and interdigitating dendritic cell sarcoma. Ann Diagn Pathol. 2015;19(3):113-6.

6. Dalia S, Jaglal M, Chervenick P, Cualing H, Sokol L. Clinicopathologic characteristics and outcomes of histiocytic and dendritic cell neoplasms: the moffitt cancer center experience over the last twenty five years. Cancers (Basel). 2014;6(4):2275-95.

7. Ventura F, Pereira $T$, da Luz Duarte $M$, Marques $H$, Pardal F, Brito C. Indeterminate cell histiocytosis in association with acute myeloid leukemia. Dermatol Res Pract. 2010;2010:569345.

8. Chen Q, Lee JS, Liang MW, Chan MMF, Pujol RM, Requena $L$, et al. Indeterminate cell histiocytosis in a Chinese patient with progressive and extensive nodular lesions and mixed indeterminate cell and macrophage-monocyte lineage. J Cutan Pathol. 2018;45(6):428-33.

9. Logemann N, Thomas B, Yetto T. Indeterminate cell histiocytosis successfully treated with narrowband UVB. Dermatol Online J. 2013;19(10):20031.

10. Horna P, Shao H, Idrees A, Glass LF, Torres-Cabala CA. Indeterminate dendritic cell neoplasm of the skin: a 2-case report and review of the literature. $J$ Cutan Pathol. 2017;44(11):958-63.

11. Sahuquillo-Torralba A, Navarro-Mira MA, LlavadorRos M, Botella-Estrada R. Indeterminate cell histio- 
cytosis in children: a case report. Actas Dermosifiliogr. 2017;108(9):871-4.

12. Oh CW, Ivan D, Curry JL, Ellis R, Gerber H, Duvic $\mathrm{M}$, et al. A case of indeterminate dendritic cell tumor presenting with leonine facies. J Cutan Pathol. 2016;43(2):158-63.

13. Facchetti F, Pileri SA, Lorenzi L, Tabanelli V, Rimsza L, Pittaluga S, et al. Histiocytic and dendritic cell neoplasms: what have we learnt by studying 67 cases. Virchows Arch. 2017;471(4):467-89.

14. Davick JJ, Kim J, Wick MR, Gru AA. Indeterminate dendritic cell tumor: a report of 2 new cases lacking the ETV3-NCOA2 translocation and a literature review. Am J Dermatopathol. In press. DOI: 10.1097/ DAD.0000000000001191.

15. Shimono J, Miyoshi H, Arakawa F, Sato K, Furuta T, Muto R, et al. Prognostic factors for histiocytic and dendritic cell neoplasms. Oncotarget. 2017;8(58):98723-32.

16. Hervier B, Haroche J, Arnaud L, Charlotte F, Donadieu J, Néel A, et al. Association of both Langerhans cell histiocytosis and Erdheim-Chester disease linked to the BRAFV600E mutation. Blood. 2014;124(7):1119-26.

17. Xu XL, Bu WB, Zong WK, Sun JF. Indeterminate cell histiocytosis: a case series and review of the literature. Eur J Dermatol. 2017;27(5):559-61.

18. Li Y, Bai HX, Su C, Zhang G. Generalized indeterminate cell histiocytosis presenting as eroded papules and crusts. Am J Dermatopathol. 2017;39(7):542-4.

19. Emile JF, Abla O, Fraitag S, Horne A, Haroche J, Donadieu J, at al. Revised classification of histiocytoses and neoplasms of the macrophage-dendritic cell lineages. Blood. 2016;127(22):2672-81.

\section{Histiocistoza indeterminantnih ćelija - prikaz slučaja i pregled literature}

\section{Sažetak}

Uvod. Histiocitoza indeterminantnih ćelija je retko proliferativno oboljenje histiocita koje je opisano u literaturi kao pojedinačni slučajevi kod oko 50 pacijenata. Javlja se u vidu žuckastih, crvenih ili smeđih papula i nodusa kod zdravih odraslih osoba. Indeterminantne ćelije su različite dendritične ćelije kože koje imaju ultrastrukturne sličnosti sa epidermalnim Langerhansovim ćelijama, ali ne sadrže karakteristične Birbekove granule, niti eksprimiraju langerin u poređenju sa Langerhansovom histiocitozom. Histiocitoza indeterminantnih ćelija je redak entitet sa promenljivim kliničkim, histopatološkim ili imunohistohemijskim nalazima, koji dele morfološke i imunofenotipske karakteristike histiocitoza Langerhansovih i non-Langerhansovih ćelija. Prikaz slučaja. Predstavljamo slučaj indeterminantne histiocitoze kod 77-godišnjeg muškarca sa trogodišnjom istorijom asimptomatskih, multiplih, crvenkastih i smeđih papula i nodula na celom telu, uključujući i oralnu mukozu. Histopatološkom analizom bioptata kože uz imunohistohemiju ukazao je na pozitivno bojenje ćelijskih infiltrata na CD68, CD1a i S-100 što je omogućilo postavljanje dijagnoze histiocitoze indeterminantnih ćelija. Osim toga, detektovana je BRAF V600E mutacija u tumorskom tkivu. Lečenje je započeto metotreksatom uz regresiju promena na koži, ali su se posle 6 meseci promene ponovo javile, te je savetovana terapija talidomidom, zbog nedostupnosti BRAF inhibitora. Zaključak. Indeterminantna histiocitoza je retka bolest, što onemogućava standardizovani pristup dijagnostici i terapiji.

Ključne reči: Histiocitoza; Dendritske ćelije; Langerhansove ćelije; Kožne neoplazme; Retke bolesti; Ishod Terapije 